\title{
Predictors of Early Adolescent Girls’ Achievement Motivation
}

\author{
Pranita R. Jagtap ${ }^{1}$
}

\section{ABSTRACT}

The present research was an exploratory research to study the predictors of achievement motivation of early adolescent girls- socio-economic status, intelligence and academic achievement. The sample of this research work consists of 132 girls studying in secondary schools of Pune City, Maharashtra. Projective test of achievement motivation by Deo-Mohan (1986) was used to measure achievement motivation. To assess economic, educational and social status of the family, Socio-economic scale was used, developed by Dubey and Nigam (2005). Raven's (1960) Standard Progressive Matrices (SPM) was used measuring IQ. However, academic achievement of the students was determined on the basis of school mark percentages. Pearson's correlation coefficients and stepwise multiple regression was done to investigate the best pattern of variables for predicting achievement motivation. Data analysis revealed that achievement motivation of students was significantly correlated with academic achievement. No significant correlation was found between scores of achievement motivation, intelligence and socio-economic status. Results of multiple regression revealed that academic achievement was significant predictor of achievement motivation.

Keywords: Achievement Motivation, Academic Achievement, Socio-economic status, General Intelligence

India is rapidly changing. The process of urbanization and industrialization is rapidly taking place leading to boom in information technology. India has experienced significant economic growth in recent years (Yallapragada, Toma, \& Roe, 2007). Despite this progress gender differences have been observed in educational and occupational achievement. (Farmer 1987; Sophie van der Sluis Vinkhuyzen Boomsma \& Posthuma ,2010). Although there are a number of powerful women in India like Sudha Murthy, Kiran Bedi, Chanda Kochhar, Mary Kom, Saina Nehwal etc. but for the common woman in India, generally the society places her in an endless cycle of duties, which obliterates her identity as well as restrains her agency within the society. Still women face a range of problems in the areas like education, career, security and basic needs satisfaction etc. Why? Are these because of differences in achievement motivation? McClelland (1961) defines achievement motivation as 'Success in competition with some standard of excellence'. He proposed that there are two types of achievement motivation, one oriented towards avoiding failure and the other towards attaining success. The influence of an

\footnotetext{
${ }^{1}$ Research Associate- Jnana Prabodhini's Institute of Psychology (JPIP), Pune, Maharashtra, India (C) 2015 I P Jagtap; licensee IJIP. This is an Open Access Research distributed under the terms of the Creative Commons Attribution License (http://creativecommons.org/licenses/by/2.0), which permits unrestricted use, distribution, and reproduction in any Medium, provided the original work is properly cited.
} 
individual's needs and desires both have a strong impact on the direction of persons behavior. Achievement motivation is a desire to strive and excel in competition with the wholehearted purposeful deliberate act the individual is engaged in which involves an urge to get to the top in the field of one's liking or accomplish something unique (Deo-Mohan, 1986). Achievement motivation is one of the key elements that will determine the success of individual and it is important for making scholastic and occupational choices and success (Farmer 1987).

McClelland and his associates (1969) identified characteristics of the people with a strong need for achievement i.e. Person sets challenging but realistic goals, takes initiative, more persistent, self motivated, goal oriented, assumes personal responsibility for problem solving, prioritizes tasks to attain goals, takes calculated risks.

What are the factors which affect the level of achievement motivation? Educational and psychological research has identified various factors that play a role in predicting achievement motivation. A review of the literature indicates that factors like Socio-economic status of the family, environment at home, individual and school experience, intelligence etc. are related to achievement motivation (Ojha, 1991; Eccles \& Harold 1993; Pandey 2008).

Adolescence is a period of rapid physical, emotional and cognitive development. It is a time when future directions and career pathways are determined (Carnegie Council on Adolescent Development, 1989). Therefore objective of this study is to study the predictors of achievement motivation of early adolescent girls.

\section{Socio-economic status and achievement motivation}

Kuppuswamy (1980) considered that education, occupation and income of parents are the important factors of socioeconomic status of family. Higher and middle socioeconomic status families provide better facilities such as better residential areas, good home library, periodicals, newspapers etc. to their children which lead to high achievement motivation. Low socioeconomic status families can't provide such type of facilities, which leads to low level of achievement motivation.

Cassidy and Lynn (1991) show that socioeconomic and family background is predictive of nAch. Agrawal (1974) investigated the correlations between achievement motivations across SES, findings revealed that achievement motivation was positively significant with SES. Study by Parikh (1976) revealed positive correlation between achievement motivation and SES. However few research studies showed no significant correlations between achievement motivation and SES. Adsul and Kamble (2008) studied the impact of economic background of family on achievement motivation of under graduate students. Finding revealed no significant differences in achievement motivation across three levels of economic background of family. Crystal, Burns, and Barbara (2011) examined achievement motivation orientation in preschool children from low and middle income families. Children did not differ in motivation orientation. Same results 
were found in the study conducted on Muslim and non Muslim students, studying in X class secondary schools by Siddiqui \& Parveen (2014). After reviewing above research articles it was observed that individuals' desire to strive and an urge to get to the top is not influenced by socioeconomic status of students' family.

Here older studies indicate that SES and achievement motivation are related, but newer studies have shown no relation.

\section{Achievement motivation and Academic Achievement}

Studies show that achievement motivation of adolescents play a significant role in determining their academic achievement. Research review showed that those who are high on achievement motivation are high on academic achievement. Gupta, Devi \& Pasrija (2012) conducted study to find the effect of achievement motivation on the academic achievement of adolescents. Results revealed that male \& female adolescents with high achievement motivation demonstrated significantly better academic achievement as compared to low achievement motivation of adolescents. Researchers conducted study on different groups to explore relationship between achievement motivation and academic achievement (Noorjehan and Wajiha ,2009, Pandey 2008, Alam 2001 ,Devanesan 1999, Harikrishan, 1992, Baskaran 1991, Saraswat 1988) all reported that there was a significant positive correlation between achievement motivation and academic achievement.

\section{Gender differences in Achievement motivation}

The difference in the achievement motivation between males and females has always been a topic that psychologists are interested in. Article that reviews the results of several studies suggests that men are more achievement oriented as compared to women (Farmer 1987). Another review across gender differences in achievement motivation is taken by Meece, Glienke, Burg (2006) indicated that motivation-related beliefs and behaviors of girls and boys continue to follow gender role stereotypes. Research conducted on students showed that male students are high on achievement motivation than female students. (McClelland J.1983, Awasthi 2002, Adsul \& Kamble 2008, Qizhen Zhu 2009,). A study conducted by Sophie van der Sluis Vinkhuyzen Boomsma \& Posthuma (2010) revealed significant sex differences in the factor future orientation. Women think less about the future than men. Research by Schultheiss, Brunstein (2001) showed that women indicated significantly higher nAffiliation than men, but they were not high in nPower, and nAchievement on TAT measure. Darshan (2001) studied 1400 students from $11^{\text {th }}$ class. The study revealed that female students were highly achievement oriented in comparison to male students. Some of the researches showed no significant gender differences in achievement motivation. (Elias, Rafaei \& Rahman 1995, Behera, 2002 Kaushik \& Rani, 2005, Nagarathanamma and Rao, 2007 Adsul and Kamble, 2008) 


\section{Predictors of Early Adolescent Girls' Achievement Motivation}

\section{Achievement motivation in relation to Intelligence}

Gagné \& Père (2002) studied 200 female high school students. Study results reported that IQ and motivation were not correlated but researches by Behera (2002) \& Varma (2003) found positive and significant correlation between intelligence and achievement motivation.

In Indian context, Gupta (1983) and Singh R. (1986) found significant correlation between achievement motivation and Intelligence. Chauhan (1984) found that achievement motivation of students differed significantly at different levels of intelligence viz. high, middle and low. Mian (1988) found that high intelligence scorers are high on nAch as compared to low scorers in intelligence.

Some research studies revealed close connection between achievement motivation and intelligence while few others showed no connections.

\section{OBJECTIVES}

- To study the correlation of achievement motivation with socio-economic status, intelligence and academic achievement

- To study the predictors of achievement motivation in early adolescent girls

\section{METHOD}

\section{Research design}

An exploratory method of research was used in this research.

\section{Participants and procedure}

Total 132 participants were involved in research from Marathi medium schools in Pune city located in Maharashtra. Sample was incidental. Before data collection permission from school authorities and consent from participants were taken.

\section{Measures}

1) Deo-Mohan Projective Test of Achievement motivation test (n-Ach)

This test is developed by Deo, P. and Mohan A. (1986). It is projective test which measures achievement motivation of adolescents. There are two separate sets for boys and girls. Students will be asked to see the picture carefully for 30 seconds and write story within four minutes with the help of four questions given in the test. Test-retest reliability and Inter scorer reliability coefficients are high (Between research scholars and lecturers 0.91). The test validated against an internal criterion- a local constructed scale of achievement motivation.

2) Socio-economic Status scale (Urban)

Socio-economic scale is developed by Dubey L. and Nigam B. (2005), which assesses economic, educational and social status of the family. Test-retest reliability of the test is 
found to be 0.81 and validity measures by judges; correlation coefficient of scores of these judges is 0.62 . Norms were developed on the basis of sample of 520 student representative of various socio economic strata. Norms are computed considering normality.

3) Standard Progressive Matrices (SPM)

This is a figural test of intelligence measuring general intelligence and ability of reasoning and problem solving (Raven, 1960). This test has high test retest reliability. Convergent validity is ranging from 0.49 to 0.81 . Indian norms are available in percentile ranks.

\section{4) Academic Achievement}

School marks of students are considered as their academic achievement. Term exam conducted in schools and total marks in theory papers were converted into percentages. Official records of students were considered as an Academic Achievement.

\section{RESULTS \& DISCUSSION}

The Data was collected and was analyzed using SPSS (version 17). Results of correlation and multiple regressions are given below-

Table 1. Pearson's correlation coefficients between achievement motivation and socioeconomic status, intelligence and academic achievement

\begin{tabular}{|l|l|l|l|}
\hline & $\begin{array}{l}\text { Achievement } \\
\text { motivation }\end{array}$ & $\begin{array}{l}\text { General } \\
\text { Intelligence }\end{array}$ & $\begin{array}{l}\text { Socio- } \\
\text { Economic } \\
\text { Status }\end{array}$ \\
\hline Intelligence & .12 & & \\
\hline $\begin{array}{l}\text { Socio-Economic } \\
\text { Status }\end{array}$ & .01 & -.01 & \\
\hline $\begin{array}{l}\text { Academic } \\
\text { Achievement }\end{array}$ & $.35^{* * *}$ & $.37^{* * *}$ & .09 \\
\hline
\end{tabular}

Achievement motivation of students was significantly correlated with academic achievement of the students $\mathrm{r}=.35, \mathrm{p}<.001$. It shows that those who were high on achievement motivation also get higher academic achievement in school exam. Their desire to strive and excel, act towards goal is reflected in their academics. Various studies revealed that achievement motivation of students plays a significant role in determining their academic achievement (Noorjahan and Wajiha ,2009, Pandey (2008), Alam (2001) ,Devanesan (1999), Harikishan (1992), Baskaran (1991), Saraswat (1988). Current finding is in congruence with earlier findings.

No significant correlation was found between scores on achievement motivation and intelligence. It demonstrates that students with high intelligence didn't show high achievement motivation or 
vice a versa. Same finding was observed in studies by Gagné \& Père (2002), they studied 200 female high school students. Current finding was not supported in earlier research.(Behera, (2002) \& Varma, (2003) Gupta, (1983) and Singh R., (1986).

Socio-economic status was not correlated with intelligence, achievement motivation, and academic achievement. It means influence of socio-economic class which students belong to can't predict their achievement motivation, academic achievement and level of intelligence. Adsul and Kamble (2008) studied under graduate students, Day and Burns (2011) studied preschool children and Siddiqui \& Parveen (2014) X class secondary students, though the sample was different in all studies results were same which denoted no significant correlation between socio-economic status and achievement motivation. So here statement by Kuppuswamy (1980) was rejected that higher and middle socioeconomic status families provide better facilities which lead to high achievement motivation. Current results were contradictory with studies by Cassidy and Lynn (1991), Agrawal (1974) and Parikh (1976) which indicate positive relation between nAch and SES.

Table 2. Regression Analysis Summary for Variables Predicting Achievement Motivation

\begin{tabular}{|l|l|l|l|}
\hline & B & SE B & $\boldsymbol{\beta}$ \\
\hline Constant & -11.77 & 4.90 & \\
\hline $\begin{array}{l}\text { Academic } \\
\text { Achievement }\end{array}$ & 0.03 & .01 & $.35^{* * *}$ \\
\hline \multicolumn{1}{|c|}{$\triangle$} & Note: $R^{2}=.12$ & $R^{2}=.122^{* *} p<.001$ \\
\hline
\end{tabular}

A stepwise multiple regressions are carried out in order to investigate the best pattern of variables for predicting achievement motivation. Academic achievement explains $12 \%$ of the variance in achievement motivation scores. Achievement motivation was associated with academic achievement. Socio-economic status and intellectual ability were not included in the analysis as they were not found to be significant independent predictor of achievement motivation.

\section{CONCLUSION}

- Students' achievement motivation was significantly correlated with academic achievement.

- There was no significant correlation was found between scores of achievement motivation and intelligence.

- Achievement motivation and socio-economic status was not correlated with intelligence.

- Results of multiple regression revealed that achievement motivation was associated with academic achievement, explains $12 \%$ of the variance in achievement motivation. Socio- 
economic status and intellectual ability were not included in the analysis as it was not significant, independent predictor of achievement motivation.

\section{REFERENCES}

Adsul, R. and Kamble, V. (2008).Achievement Motivation as a Function of Gender, Economic Background and Caste Differences in College Students. Journal of the Indian Academy of Applied Psychology, 34 (2), 323-327.

Agrawal, P.G. (1974), A study of correlates of achievement motivation, Ph.D in education, U.P (170), In Buch, M.B, Second survey of research in education.

Alam, M.M. (2001). Academic Achievement in Relationship to Socio-Economic Status, Anxiety Level and Achievement Motivation: A Comparative Study of Muslim and Non-Muslim School Children of Uttar Pradesh. (Unpublished doctoral dissertation). Aligarh Muslim University.

Awasthi B. (2002). Role of sex, IQ and SES in developing achievement motivation. Psycholingua. 32, (2), 107-112

Baskaran, K. (1991), Achievement Motivation, Attitude toward Problem-Solving and Achievement in Mathematics of Standard X Students in Devakottai Educational, District. Ph.D. (Education), Alagappa University.

Behera, A.K.(2002) Intelligence Achievement Motivation and Personality of Vocational Students in relation to Academic Achievement. Ph.D. (Education), Punjab University.

Abstract Retrieved from http://www.ncert.nic.in/html/pdf/Publication/Journal2008/IEA_July2006/IEA_July06.pdf

Carnegie Council on Adolescent Development (1989) Turning Points: Preparing American Youth for the 21st Century. Carnegie Corporation, New York. Retrieved March, 2010, from http://carnegie.org/fileadmin/Media/Publications/PDF/GREAT\%20TRANSITIONS.pdf

Cassidy, T. \& Lynn, R. (1991) Achievement motivation, educational attainment, cycles of disadvantage and social competence: some longitudinal data. British Journal of Educational Psychology, 61, 1-12.

Chauhan, S.S. (1984).A Comparative Study of Achievement Motivation of Scheduled Tribe and Scheduled Caste Students of Himachal Pradesh in relation to Intelligence and SocioEconomic Status, Retrieved March, 2010

Crystal A. and Burns, Barbara M.(2011). Characterizing the Achievement Motivation Orientation of Children from Low and Middle Income Families. Early Education \& Development, 22(1), 105 -127 To link to this Article: DOI: 10.1080/10409280903544397

Darshan (2001). A study of Manifest Anxiety among Adolescents in relation to certain Cognitive and Non-Cognitive Variables. Ph.D., M.D.University. Abstract retrieved from http://www.ncert.nic.in/html/pdf/Publication/Journal2008/IEA_July2006/IEA_July06.pdf

Deo P. \& Mohan A. (1986) Manual of Deo-Mohan Projective Test of Achievement Motivation., Agra: National psychological corporation. 
Devanesan, Paul, P. (1999). Socio-economic Status, Achievement Motivation and Academic Achievement of Higher Secondary Students in Pasumpon, Thevar Thriumagan District. (Unpublished Master's thesis). Education, Alagappa University.

Diseth A. (2002). The Relationship between Intelligence, Approaches to Learning and Academic Achievement. Scandinavian Journal of Educational Research.46 (2), 219-230

Dubey L. \& Nigam B (2005) Manual of Socio-Economic Scale (Urban). Jabalpur: Arohi Manovigyan Kendra.

Eccles, J. S. \& Harold, R. D. (1993). Parent-school involvement during the early adolescent years. Teachers College Record, 94 (3), 568-588.

Elias, H., \& Rahman, W. R. A. (1994). Achievement motivation training for university students: Effects of affective and cognitive achievement motivation. Pertanika Journal of Social Sciences \& Humanities, 2(2), 115-121.

Farmer H. S. (1987). A Multivariate Model for Explaining Gender Differences in Career and Achievement Motivation. Educational Researcher, 16(2), 5-9.

Field, A. (2009). (Third Ed.).Discovering Statistics Using SPSS. London: Sage Publications Ltd.

Gagné, F. \& Père, F. (2002). When IQ is controlled, does motivation still predict achievement? Intelligence, 30(1), 71-100. http://aer.sagepub.com/cgi/content/abstract/20/4/503

Gupta M., Devi M., Pasrija P. (2012). Achievement Motivation: A Major Factor in Determining Academic Achievement. Asian Journal of Multidimensional Research, 1(3), 131-145.

Retrieved from http://www.tarj.in http://journalistsresource.org/studies/international/human-rights.dpuf

Harikrishan, M. (1992), A Study of Academic Achievement of the Students of the Higher Secondary Stage in Relation to Achievement Motivation and SES. (Unpublished Master's dissertation) .Annamalai University.

http://www.education.nic.in/cd50years/g/z/9I/toc.htm

Kaushik, N \& Rani, S. (2005). A Comparative study of achievement motivation, home environment and parent child relationship of adolescents. Journal of Psychological research, 49, 189-194.

Kuppuswamy, (1980). An introduction to social psychology. Bombay: Asia Publishing House.

Laidra K.2Pullmann H., Allik J. (2007). Personality and intelligence as predictors of academic achievement: A cross-sectional study from elementary to secondary school. Personality and Individual Differences, 42(3), 441-451

McClelland, D. C. (1961) The Achieving Society. Princeton, N.J.: Van Nostrand.

McClelland, D.C., \& Winter, D.G. (1969). Motivating economic achievement. New York: Free Press.

McClelland, J.W. (1983). A study of gender differences in motivation of high achieving students in a southern private college preparatory school. (Unpublished doctoral dissertation). University of Alabama.

Meece J., Glienke B., Burg S. (2006). Gender and motivation. Journal of School Psychology $44,351-373$ 
Nagarathnamma, B \& V. Thirumal, Rao (2007). Achievement motivation and Academic Achievement of adolescent Boys and Girls. Indian Psychological Review, 68, 131 -136.

Noorjehan, N.; Ganihar, Wajiha A.H., Edutrack (2009). Factors Affecting Academic Achievement of IX Standard students in Mathematic. 8(7)

Ojha, H. (1991).The Origin of Achievement motivation. New Delhi: Classical Publicating Company.

Pandey, R.C. (2008). Academic achievement as related to achievement motivation and parental background. Indian Psychological Review, 70(4), 213-216.

Parikh, P.A. (1976), A study of achievement motivation, school performance and educational norms of Secondary School pupils of standard VII,IX and X in the city of Bombay, Buch, M.B, Second Survey of Research in Education, Society For Educational Research and Development, Baroda, 189-190.

Qizhen L. Zhu X. (2009). Investigation and Analysis on the Achievement Motivations of Senior High School Students. International Journal of Psychological Studies. 1(1) www.ccsenet.org/journal

Raven, J.C., (2000). Manual for Standard Progressive Matrices (SPM). USA Education.

Saraswat, A. (1988). A Differential Study of Achievement Motivation, Occupational Aspiration and Academic Achievement of Adolescents in Different Types of School Climate in Aligarh district. (Unpublished doctoral dissertation) . Agra University.

Schultheiss O.C., Brunstein J.C. (2001). Assessment of Implicit Motives with a research version of the TAT: Picture profiles, Gender Differences, and Relations to Other Personality Measures. Journal of Personality Assessment, 77(1), 71-86

Siddiqui,M., Parveen.A. (2014). Study of Achievement Motivation In Relation To Self Concept and Socio Economic Status Among Muslim And Non- Muslim Adolescents. Research journali's Journal of Education, 2 (3) Retrieved from www.researchjournali.

Singh, M. (2011), Academic Achievement Motivation of Aided Schools Adolescents, Indian Journal of Psychometry and Education, 42(2), 128-129.

Singh, R.S.(1986). A Study of Achievement Motivation, Level of Aspiration and Anxiety as Correlates of Creativity in Denotified Tribal Children, Ph.D. Edu., Retrieved March, 2010 http://www.education.nic.in/cd50years/g/z/9l/toc.htm

Sophie van der Sluis Vinkhuyzen A. Boomsma D. \& Posthuma D.(2010). Intelligence, 38 433446.

SPSS Inc. (2008).SPSS 17.0 for windows. SPSS Inc, Chicago

Varma, M.K. (2003). Relationship of Academic Achievement of Middle School Students with their Intelligence, Adjustment and Achievement Motivation. (Unpublished doctoral dissertation). Bundelkhand University.

White, Karl R. (1982). The relation between socioeconomic status and academic achievement. white Psychological Bulletin, 91(3), 461-481.http://psycnet.apa.org/journals/bul/91/3/461

Yallapragada, R. R., Toma, A. G., \& Roe, C. W. (2007). India: The Future Economic and Knowledge Super Power? International Business \& Economics Research Journal, 6(2) 